\title{
Analysing the environmental harms caused by coal mining and its protection measures in permafrost regions of Qinghai-Tibet Plateau
}

\author{
*State Key Laboratory of Frozen Soil Engineering, Northwest Institute of \\ Eco-Environment and Resources, CAS, Lanzhou 730000, China \\ ${ }^{* *}$ Corresponding author. E-mail address: sheng@Izb.ac.cn.
}

Keywords: permafrost; environmental harms; coal mining; protection measures

\begin{abstract}
The coal mining has brought a series of ecological problems and environmental problems in permafrost regions. Taking Muli coalmining area as an example, this article attempts to analyse the environmental harms caused by coal mining and its protection measures in permafrost regions of Qinghai-Tibet Plateau. This article analyses the influence of open mining on the surrounding permafrost around the open pit by using the numerical simulation The results show that (1) based on the interrelation between coal mining and permafrost environment, these main environmental harm include the permafrost change and the natural environment
\end{abstract}

(C) IOŚ-PIB

The region of Muli-Jiangcang-Reshui is located in the south of Qilian Mountains. It is the water source area of Qinghai Lake and the Datong River [Zhang and Gao 1981]. This region is also one of the most important wetland protection areas and ecological environment in China, especially in Qinghai Province. However, Muli Coalfield belongs to the Alpine permafrost zone of Altun-Qilian Mountains in Qinghai-Tibet Plateau [Zhou et al. 2000]. The coal mining will bring a series of ecological and environmental problems in permafrost regions [Makarov 2004; Wang 1993, 1996; Zheng and Ma 1999, 2000]. Therefore, the problem of environmental protection has been increasingly paid attention to under the influence of the rapid development of economy and society in cold regions [Cheng et al. 2008; Jin et al. 2008; Zhang et al. 2008; Wang et al. 2000]. It is highly important to avoid and reduce the impact of coal mining on the frozen-soil environment. Environmental protection should have priority over resource exploitation in permafrost regions [Hildebrand 1983; Jin et al. 2006, 2009; Peretrukhin and Potaueva 1983]. Therefore, this paper intends to analyse the permafrost environment problems in the process of Muli coal mining. And this article also applies the method of numerical simulation to analyse the influence of open mining on the permafrost environment in the mining pit. Finally, the study puts forward some useful suggestions and countermeasures to avoid and reduce the impact of coal mining on the permafrost environment. It provides a scientific basis for the resource development and environmental protection in cold regions. change in cold regions; (2) once the surface temperature rises due to open mining, the permafrost will disappear with the increase of exploitation life. If considering the solar radiation, the climate conditions and the geological condition around the pit edge, the maximum thaw depth will be more than $2 \mathrm{~m}$; (3) the protection measures are proposed to avoid the disadvantage impact on the permafrost environment caused by coal mining. It will provide a scientific basis for the resource development and environment protection in cold regions.

\section{INTRODUCTION OF COAL MINING AREA}

Muli coal-mining area $\left(98^{\circ} 59^{\prime}-99^{\circ} 37^{\prime} 36^{\prime \prime} \mathrm{E}, 38^{\circ} 10^{\prime}-38^{\circ} 01^{\prime} 59^{\prime \prime} \mathrm{N}\right)$ is located in Tianjun County and Gangcha County, in the northeast of Qinghai Province (Fig. 1). The mining area is composed of Jiangcang zone, Juhugeng zone, Hushan zone and Duosuogongma zone. The terrain is hilly and plain with low in the southeast and high in the northwest. The elevation is $3,750-3,950 \mathrm{~m}$ in Jiangcang district located in the southeastern part of the mining area. And the elevation is 4,000-4,200 $\mathrm{m}$ in Juhugeng district located in the northwestern part of the mining area. The mine is situated in the south bank of the Datong River basin's upstream, in the middle of Qilian Mountain. In the region, the land type is prairie valley. This region is filled with the marsh in the summer, composed of puddles of different size and several small lakes. Owing to the location in the alpine zone, the annual average temperature is $-4.2^{\circ} \mathrm{C}$. And the highest and minimum temperature is $19.8^{\circ} \mathrm{C}$ and $-35.6^{\circ} \mathrm{C}$, respectively. The annual rainfall is $477.1 \mathrm{~mm}$, mostly in the summer. Annual evaporation capacity is $1,049.9 \mathrm{~mm}$. The wind blows in the west or southwest direction all year long. The maximum wind speed is greater than $40 \mathrm{~m} / \mathrm{s}$, and the average wind speed is $2.9 \mathrm{~m} / \mathrm{s}$.

Muli Coalfield is the largest coal reserves in Qinghai Province, accounting for the province's total reserves of $8 \%$. In 2020 , the coal output is expected to reach to $20,000,000$ tons and the production capacity of coal chemical industry reaches to 


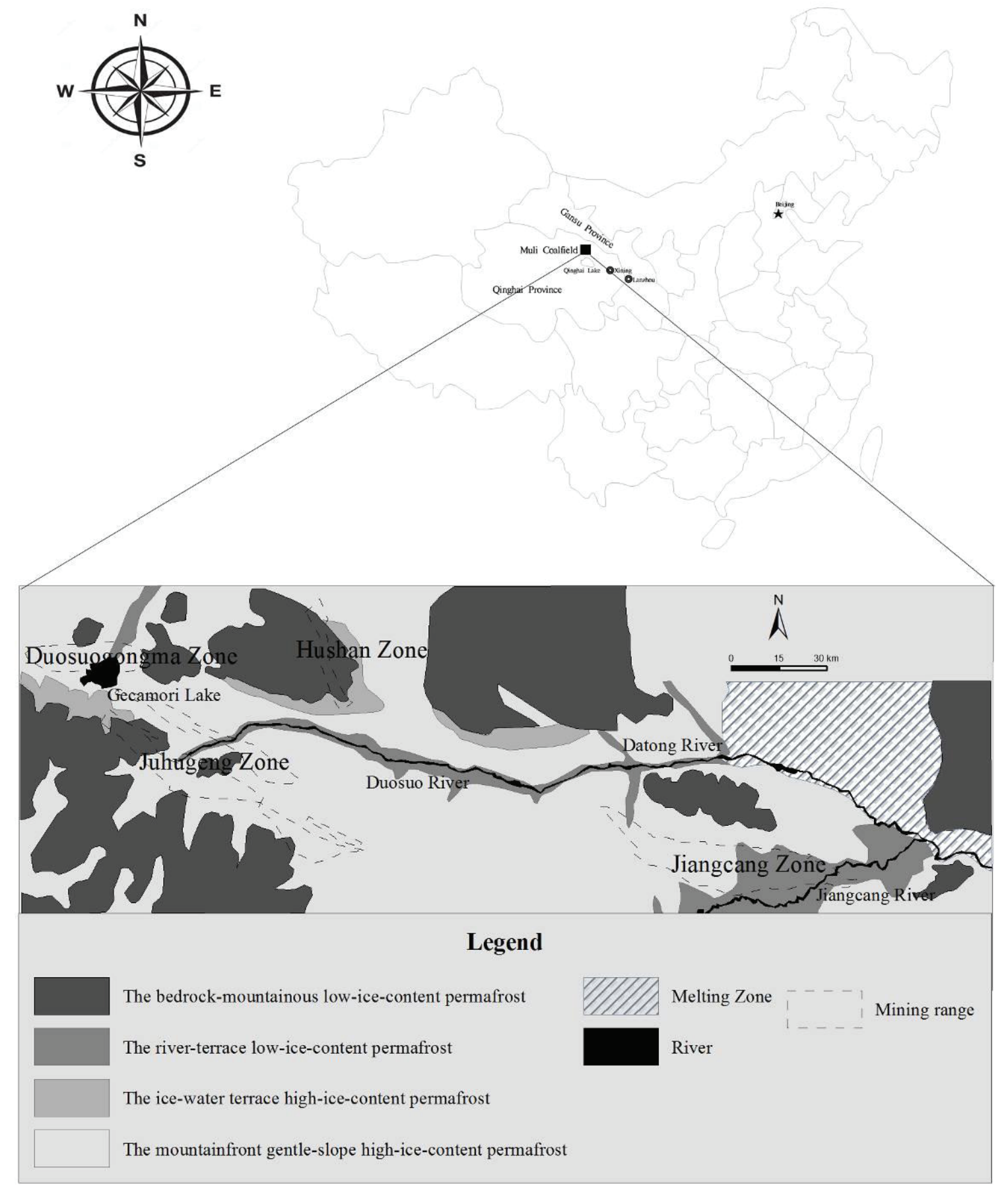

Figure 1. A map of the frozen-soil type in Muli coalfield mining area.

$12,000,000$ tons. The coal-bearing strata of Jiangcang District are located in the south of Datong River Basin. This region belongs to the subsidence centre and the coal-rich zone in the Muli Coalfield. The thickness of coal-bearing strata is about 658 $\mathrm{m}$. There are abundant coal layers from top to bottom in the ground. The thickness of the coal seam is $95.51 \mathrm{~m}$, and that of the mining is $44.87 \mathrm{~m}$. Juhugeng District contains five to six layers of recoverable coal seam. Most of the coal seams are not stable and unworkable. The No. 1 well of Jiangcang mining area was small scale and exploited in 1971. Because of the immature developmental condition, the mine was discontinued in 1979 . The No. 2 well of Juhugeng mining area was small-scale openpit mined in 1985. In 2002, the mining depth reached to $30 \mathrm{~m}$ and the total amount of coal mining was about 458,000 tons. At present, the coalfield has been open-pit mined and has initially built a certain production capacity in the No. 1 well of Jiangcang mining area and the No. 1 and No. 2 well of Juhugeng mining area. The coalfield in Hushan zone and Duosuogongma zone was undeveloped [Cao et al. 2008, 2010]. 


\section{PERMAFROST DISTRIBUTION AND CHARACTERISTICS OF MINING AREA}

\subsection{Permafrost Distribution}

Muli Coalfield is located in the Alpine permafrost zone of AltunQilian Mountains in Qinghai-Tibet Plateau. The coalfield is situated between Tolai mountain and Datong mountain located in the middle section of Qilian mountain. Owing to the control of altitude and latitude, this district is largely covered by continuous permafrost. Regional latitude variation is relatively small, so the altitude is a dominant factor to control the permafrost development. This will lead the river to form breakthrough or nonbreakthrough talik. It will lead to that the river forms breakthrough talik or non-breakthrough talik. There is a sheet of talik amongst broad valley and terrace in Datong River. Most of valley range is covered by breakthrough talik in the Datong River and Jiangcang meander. Valley range is through non-breakthrough talik in Duosuo meander. Figure 1 shows the distribution map of the permafrost in Muli coal mining of Qinghai Province. According to the topography, permafrost ice-content, lithology and thickness of unconsolidated formation, the permafrost in Muli coal mining can be divided into four types. They are the bedrock-mountainous low-ice-content permafrost, the river-terrace low-ice-content permafrost, the ice-water terrace high-ice-content permafrost and the mountainfront gentle-slope high-ice-content permafrost, respectively.

\subsection{Main characteristics of permafrost}

The river-terrace low-ice-content permafrost is mainly distributed at both sides of Duosuo meander in Juhugeng District, both sides of Jiangcang meander in Jiangcang District and both sides of the Datong River (Fig. 2a). The flat terrain and the dense branches in Jiangcang meander near the mining area results in the formation of a wide range of terrace low-ice-content permafrost. The upper part of the stratum in this region is generally $0.5-1.0 \mathrm{~m}$ of sandy loam layer and clay loam layer, and the under part is about 5-30 $\mathrm{m}$ alluvial sand-gravel layer. The lower-part of fine-particles soil is commonly micro-layer ice lens. Sand gravel is cemented by ice. And it is filled with ice inclusions to a depth of $2.0-4.0 \mathrm{~m}$. But the ice content is generally less than $20 \%$. Seasonal thawing depth is generally $1.7-2.0 \mathrm{~m}$ in this region. Owing to the thermal effect of the river near $20-\mathrm{m}$ range of river bed, the seasonal thawing depth is up to $2.5 \mathrm{~m}$ and the thickness of permafrost is about $30-50 \mathrm{~m}$. And the permafrost temperature is -0.3 to $-1.2^{\circ} \mathrm{C}$. It means that the permafrost temperature in Jiangcang District is higher and the permafrost thickness is thinner.

The ice-water terrace high-ice-content permafrost is mainly distributed in the diluvial and moraine deposit belt surrounding the gentle remnant mountains of Juhugeng District (Fig. 2b). The surface is covered by $1.0-2.0 \mathrm{~m}$ of alluvial gravel in the region. Below the surface, there is a layer of boulder sand-gravel and moraine with a thickness of 20-30 m. The deep bedrock fissurewater rises out of the surface along the loose rock in certain sections. It leads to the spring exposed in the surface. Soil and stone is cemented by ice in moraine layer, and the ice content is

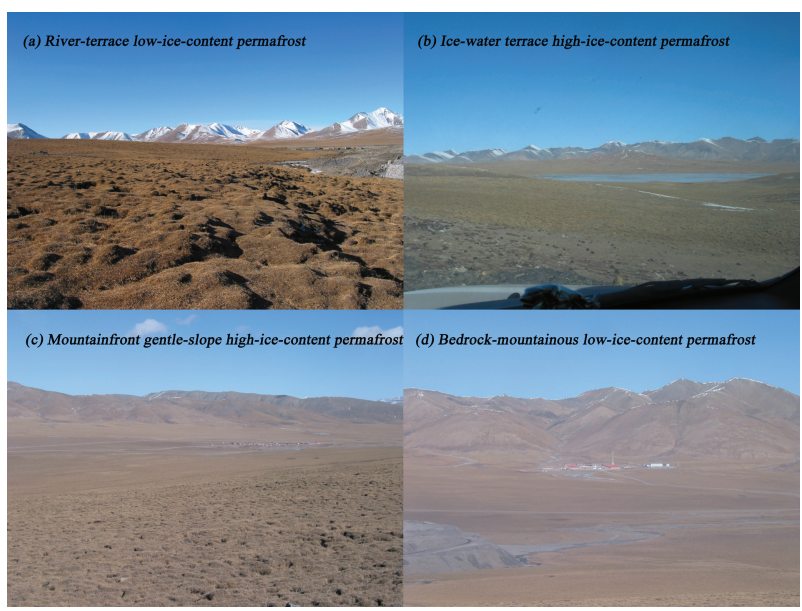

Figure 2. Photographs for the landform type in Muli mining area.

about $15 \sim 30 \%$. The seasonal thawing depth is $1.8-2.0 \mathrm{~m}$. The permafrost thickness and temperature is $50-70 \mathrm{~m}$ and -1.0 to $-1.5^{\circ} \mathrm{C}$, respectively.

The mountainfront gentle-slope high-ice-content permafrost extensively distributes in Muli Coalfield. This type of permafrost is mainly distributed in loose moraine layer, diluvial layer and alluvial layer of the mountainfront gentle-slope zone (Fig. 2c). The surface is covered by the marsh and frost-heaving grassmound. There is about $0.5-\mathrm{m}$ peat layer under the turf. Below the peat layer, there is $2.0-$ to $3.0-\mathrm{m}$ black loam and sandy loam, which contain a certain amount of gravel. Under the fine-grained soil, mostly there is $15-$ to $25-\mathrm{m}$ thick moraine sand layer. Below the surface with the depth range of $1.0-7.0 \mathrm{~m}$, there is an ice layer and its thickness is up to $9 \mathrm{~m}$ in local belt. In the lower, the high ice-content layer with a thickness of $0.3-1.0 \mathrm{~m}$ around the bedrock weathering layer appears. Seasonal thawing depth is $1.0-1.3 \mathrm{~m}$. The ice content is $40-90 \%$ in fine-grained soil layer, whereas the ice content is $15-40 \%$ in moraine layer. The permafrost thickness and temperature is $50-90 \mathrm{~m}$ and -1.0 to $-2.0^{\circ} \mathrm{C}$, respectively.

The bedrock-mountainous low-ice-content permafrost is mainly distributed in the hills and low mountain around the mining area (Fig. 2d). The upper unconsolidated formation is mainly bedrock weathering residues. And the bedrock is little exposed on the surface because of the thin loose covering with the thickness of $1 \mathrm{~m}$. Granular rubber ice is present between the lower part of unconsolidated formation and the upper part of bedrock weathering zone. The ice content is less than $10 \%$. Seasonal thawing depth is generally $3.0-4.0 \mathrm{~m}$ in sunny slope and usually $2.5-3.0 \mathrm{~m}$ in shady slope. The permafrost thickness and temperature is $30-60 \mathrm{~m}$ and -0.5 to $-1.5^{\circ} \mathrm{C}$, respectively.

The permafrost continuously distributes in mining area. The thickness of overlying loose layer is relatively thin. Especially, the rich-ice permafrost mainly concentrates in the upper loose layer. The thinner the soil, the higher is the ice content. The permafrost thickness is thin and the ground temperature is high around the hillside and river terrace. In the gentle slope and moraine platform, the permafrost thickness is thick and the ground temperature is low and the ground surface is mainly covered by 
the swamp. The permafrost is thicker and the ground temperature is lower in Juhugeng District than in Jiangcang District because of the effect of altitude control. The region mainly distributes in the mountainfront gentle-slope high-ice-content permafrost. The proportion of this permafrost type is $48.13 \%$ (Table 1 ). In addition, the proportion of the bedrock-mountainous low-ice-content permafrost is relatively high, which reaches to $37.74 \%$. The other two types of the permafrost are relatively low. The total accounts for only $7.23 \%$ of the total area.

\section{PERMAFROST ENVIRONMENTAL PROBLEMS AND HARM CAUSED BY COAL MINING}

\subsection{Permafrost change}

Currently, Muli coal mining has been partly open mined in three mining pits, including the No. 1 well of Jiangcang mining area and the No. 10 well and No. 4 well of Juhugeng mining area. The quaternary seasonal thawing layer has been peeled off in advance by using the method of speed-up stripping in the mining process. The eradication of the natural vegetation will destroy the original landform. The solar radiation increases with the formation of mining area. It breaks the balance of heat radiation. When the radiation strengthens, the temperature inside the mining pit will rise. It will lead to the increasing of evaporation. Once the local climate changes, it will cause the significant change in permafrost.

1. Coal mining exacerbates the shrink of permafrost area. The permafrost and seasonal frozen soil is covered in the Muli coal mining. Frozen-soil layer is mixed up with coal seam. In the process of coal mining, the frozen-soil layer is stripped and transported, resulting in degradation or disappearance of permafrost. The permafrost degradation and disappearance has occurred in the open-mining area. With the large-scale exploitation of the mining area, this phenomenon is more obvious. It will inevitably lead to the withdrawal of permafrost area.

2. Ice-content type of permafrost has changed, and the scope of thaw zone has continually expanded. Ice content of permafrost is a major factor of ground-surface deformation and engineering-construction destruction in permafrost regions. It is the richest part of underground ice near the upper limit of permafrost. Owing to close to the surface, the underground ice is easily affected by natural and artificial factors. The permafrost type is mainly rich-ice permafrost, saturation-ice permafrost, and including-soil ice-layer in Muli coal mining. As a result of the high ice content of permafrost, it is extremely sensitive to interference of human activities. A large number of underground ices are exposed to the surface in the process of opencast coal mining. The mine exploitation and coal mining will cause the ground ice melting. It will result in the degradation or even disappearance of the permafrost. And the scope of thaw zone has continually expanded.

3. The permafrost table decreases year by year and the ground temperature increases year by year. According to
Table1. Statistics of various permafrost types in Muli coalfield mining area.

\begin{tabular}{|c|c|c|}
\hline Type & Area $\mathbf{( h m}^{\mathbf{2}}$ ) & Proportion (\%) \\
\hline $\begin{array}{c}\text { The river-terrace low-ice- } \\
\text { content permafrost }\end{array}$ & $10,067.98$ & 5.78 \\
\hline $\begin{array}{c}\text { The ice-water terrace high- } \\
\text { ice-content permafrost }\end{array}$ & $2,522.61$ & 1.45 \\
\hline $\begin{array}{c}\text { The mountainfront gentle- } \\
\text { slope high-ice-content } \\
\text { permafrost }\end{array}$ & $83,789.4$ & 48.13 \\
\hline $\begin{array}{c}\text { The bedrock-mountainous low- } \\
\text { ice-content permafrost }\end{array}$ & $65,686.80$ & 37.74 \\
\hline The taliks & $12,005.22$ & 6.90 \\
\hline Total & $174,072.01$ & 100.00 \\
\hline
\end{tabular}

the borehole temperature data, in the 1960s, the change depth of temperature variations is in the range of $11-16 \mathrm{~m}$ in Juhugeng mining-area of Muli coalfield. The annual average temperature is -2.3 to $-0.6^{\circ} \mathrm{C}$, whereas the average annual temperature is -1.35 to $-0.24^{\circ} \mathrm{C}$ according to the borehole temperature data in the 2000s. Figure 3 shows the ground temperature curves in this mining area in the years 1969 and 2009. This shows that even if the human disturbance was small, the annual average temperature has increased year by year with the global climate warming. The largescale exploitation of mining area is bound to exacerbate this process. The destruction of natural vegetation will lead to the rise of ground temperature and the decline of the permafrost table.

\subsection{The changes in natural environment in permafrost regions}

The change in permafrost environment includes not only the frozen-soil layer but also the natural environment of climate, hydrology and land surface conditions. Both of them are interdependent and mutual influencing.

1. Destruction of plateau vegetation: Plateau ecological environment is extremely fragile. Once the vegetation suffers serious damage, the ecosystem cannot be restored for a long term. The destruction of vegetation results in surface desertification. It will change the soil hydrothermal condition and the permafrost burial conditions. When the permafrost table descends and the ground ice melts, the groundwater level will decline and the surface soil moisture will reduce. This change in turn will make the surface drier. Then the surface desertification intensifies and will lead to the hot-Karst phenomenon, such as thaw slumping, thaw depression and thermokarst lake. The irreversible vicious circle will eventually lead to the deterioration of the ecological environment [Wang et al. 2001, 2004]. The natural cover layer is stripped in the process of Muli coal mining. It leads to the surface drought and desertification in the mining area. The ecological balance is broken. Especially, the arbitrary excavation doesn't pay attention to the protection of vegetation in the road construction of mining area (Fig. 4a). 


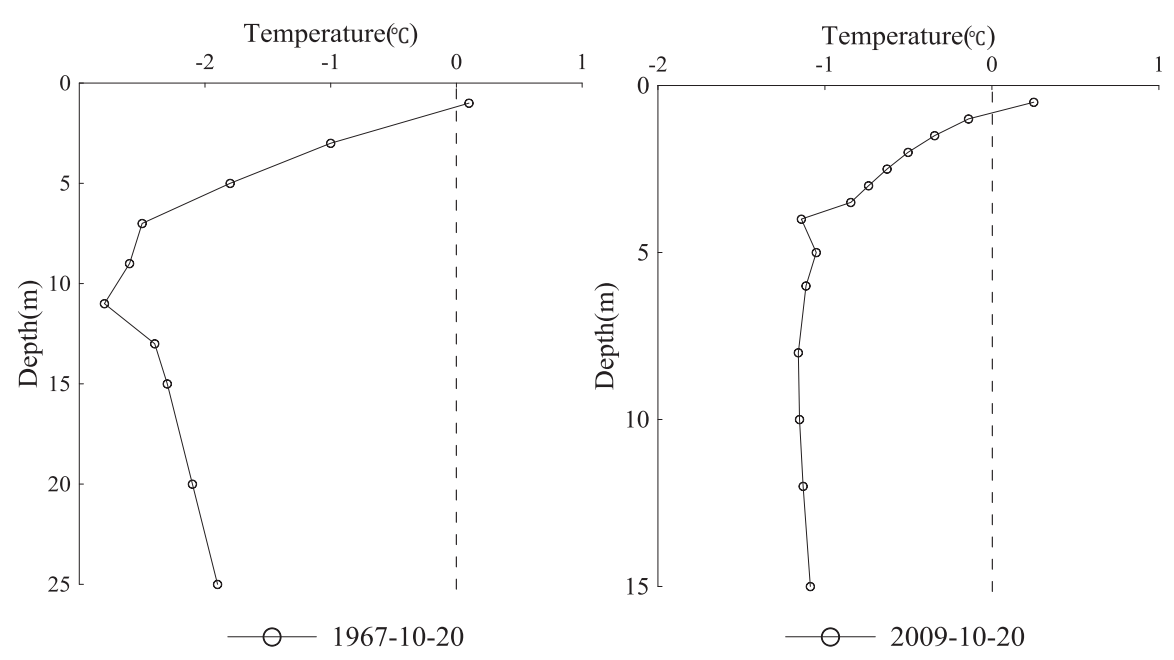

Figure 3. Comparison of the ground temperature of Muli mining area in different period.

It results in a large number of abandoned pits on both sides of the road. It results in the underground ice exposed in the surface and the formation of thaw depression. Moreover, a large area of the surface vegetation is excavated in the construction of the drainage ditch in No.4 well of Juhugeng mine district (Fig. 4b). It results in the vicinity of vegetation destroyed. The underground ice can be seen at $1-2 \mathrm{~m}$ of the excavation section below the surface. And the underground ice melting causes serious damages to the ecological environment.

2. Change in surface water: Global change and human activities will directly affect the surface condition and the freezingthawing of permafrost active layer. At the same time, they change the seasonal freezing and the release of soil moisture. Thereby, they also affect the runoff of surface water and shallow groundwater and their distribution in the year [Wang et al., 2001, 2004]. Coal mining breaks the heat exchange process in the permafrost active layer and also changes the depth of surface-water and groundwater and their migration laws. Owing to the permafrost melting and surface-water infiltration, there is a large area of stagnant-water phenomenon in the mine. Owing to the opencast mining, a mine water pit is close to the river in Jiangcang mining area (Fig. 4c). Coal mining has destroyed the permafrost layer. And the river has penetrated into the water pit through the permafrost layer. It leads to a large area of icy water phenomenon. Pumping water is a must to normally construct by the use of water pump in the winter. The No. 4 well of Juhugeng District is near to Duosuo river (Fig. 4d). Therefore, the river way is directly built with mining dump, the garage and some production facilities. Especially, the waste gangue piled on the river side directly squeezes the vegetation on the terrace. Gangue easily absorbs the solar radiation. And it will increase the overlying surface heat. Thus it breaks the balance of heat radiation and leads to the artificial permafrost-table descending, ground ice melting and the change in groundwater migration rule. A series of frost heaving and thermokarst lake phenomena appear in the side of Duosuo River, whereas dense alpine meadow grows at the

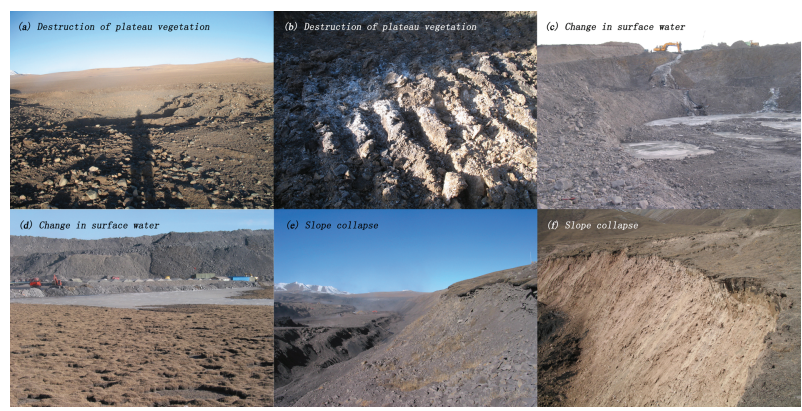

Figure 4. Photographs for the permafrost environmental change in Muli mining area.

opposite bank. Moreover, the production and living water is discharged at random to the river in the mining area. It has seriously hindered the tributary flow direction of the Duosuo River.

3. Slope collapse: In order to meet the needs of mining operations, open pit is often divided into a certain height level (or oblique) layer in the mining process, consisting of several steps. The top of coal bed is the Quaternary overburden layer, belonging to the bedrock weathering zone. The excavation of coal seam influences the permafrost and leads to the formation of seasonal thawing layer in the slope within a certain range. When the surface temperature increases and the ground ice melts, it will be easy to form traceability slump phenomenon. Especially, the loose rock is prone to collapse and avalanche [Niu et al. 2004, 2006]. In addition, if the waste rock stacks unreasonably, the overlying permafrost will be prone to collapse avalanche (Fig. 4e). Haitaer coal mine is excavated by using underground mine tunnelling. The mining depth is about $540 \mathrm{~m}$. The goaf is automatically filled and levelled up after collapsing due to coal mining. A collapse has arisen around the goaf and gradually extended to the surrounding after digging coal (Fig. 4f). The depth of the nearest collapse is about 50-60 $\mathrm{m}$. The diameter of the emerging pits is about $30-100 \mathrm{~m}$. 


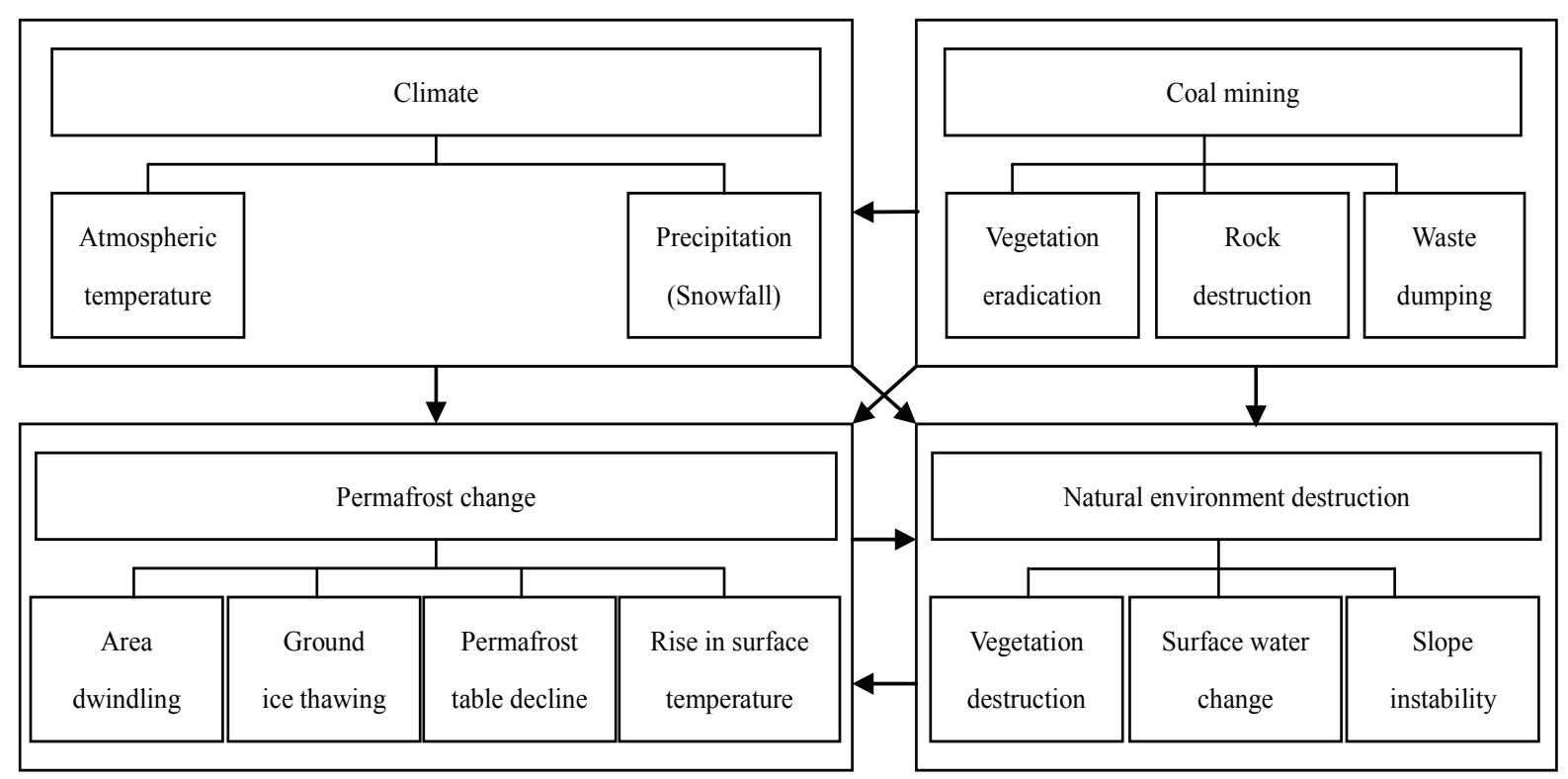

Figure 5. Interaction between coal mining and permafrost environment.

The landslide and collapse appears around the pits because of the thawing of ground ice. Moreover, the ground fissure with a depth of 50-60 $\mathrm{cm}$ appears to the peripheral at 10$12 \mathrm{~m}$ and reduces gradually to the periphery. The range of subsidence effect extends several miles. The main reason is that the overlying permafrost is disturbed and ground ice melts due to the rise in top temperature of coal seam.

\section{SIMULATION FOR THE INFLUENCE OF COAL MINING ON THE PERMAFROST}

\subsection{Analysis the interaction between coal mining and permafrost environment}

The permafrost environment is mainly affected by internal and external factors [Wu et al. 2000]. The internal factors primarily include soil, ice content and annual average ground temperature. The external factors generally include climate, terrain and human activities. Internal factors affect the permafrost properties, and external factors restrict the internal factors. It is complex for the interaction between coal mining and permafrost environment. But the interaction can be briefly denoted by Figure 5. Coal mining will lead to the eradication of vegetation, destruction of rock and waste dump. Once the surface temperature rises due to coal mining, it will result in heat erosion, ground ice thawing, permafrost table declining and the change in water-heat exchange process in the active layer. Moreover, coal mining will directly bring on destruction of the natural environment, such as desertification, slope instability, the change in surface water system and microclimate in mining area. The change in the natural environment has a direct impact on the change in permafrost, whilst the latter oppositely has an impact on the former, which makes mutual transformation and interaction.

\subsection{Simulation for the influence of coal mining on the permafrost}

Opencast mining will eradicate the overlying vegetation. The frozen-soil layer is also stripped from the whole. Thus, the permafrost environment is seriously damaged in the mining area. In addition, the permafrost on the excavated slope is directly exposed to the atmosphere in the open pit. This will lead to the occurrence of the slope collapse and the melt mudflow. Then the result influences the surrounding permafrost environment around the open pit. It is very complex to reveal the influence of the interaction between open mining and the permafrost environment. This is mainly due to the fact that they are affected by different climatic conditions, surface condition and geological condition. Thus, this study analyses the influence of open mining on the surrounding permafrost around the open pit by using the numerical simulation. The average temperature of the natural surface is $-1.5,-1.0$ and $-0.5^{\circ} \mathrm{C}$. The highest temperature isotherms are plotted around the open pit after open pitting through 1 year, 5 years, and 10 years.

Figure 6 shows the highest temperature isotherm with the annual mean surface temperature of $-1.5^{\circ} \mathrm{C}$. When the thickness of the active layer is $1.5 \mathrm{~m}$ around the pit bottom and edge, a thin layer of the permafrost will develop. But the thickness is only $4.8 \mathrm{~m}$ until the tenth year.

Figure 7 shows the highest temperature isotherm with the annual mean surface temperature of $-1.0^{\circ} \mathrm{C}$. When the thickness of the active layer is $1.4 \mathrm{~m}$ around the pit bottom and edge, a thin layer of the permafrost will develop. But the thickness is only $4 \mathrm{~m}$ until the tenth year.

Figure 8 shows the highest temperature isotherm with the annual mean surface temperature of $-0.5^{\circ} \mathrm{C}$. When the thickness of the active layer is $1.5 \mathrm{~m}$ around the pit bottom and edge, a thin layer 


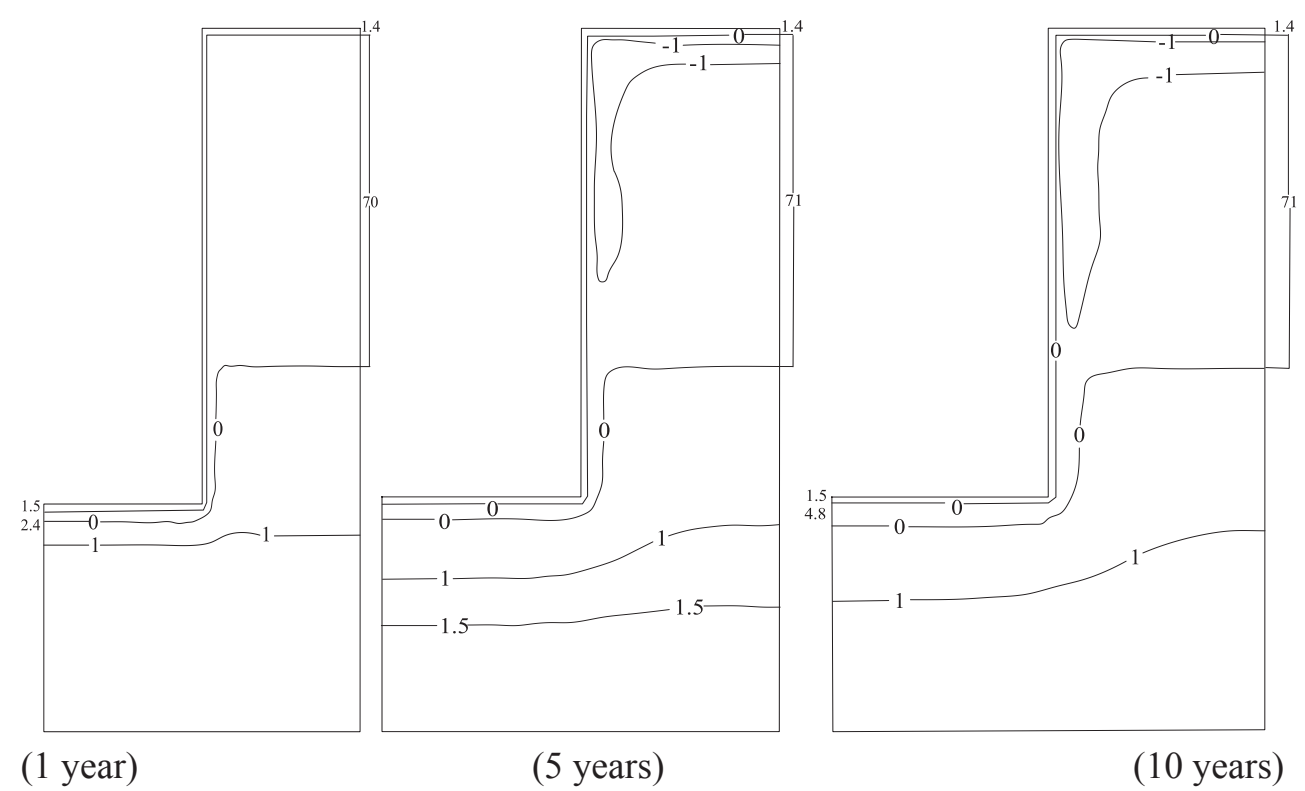

Figure 6. The highest temperature isotherm with the annual mean surface temperature of $-1.5^{\circ} \mathrm{C}$.

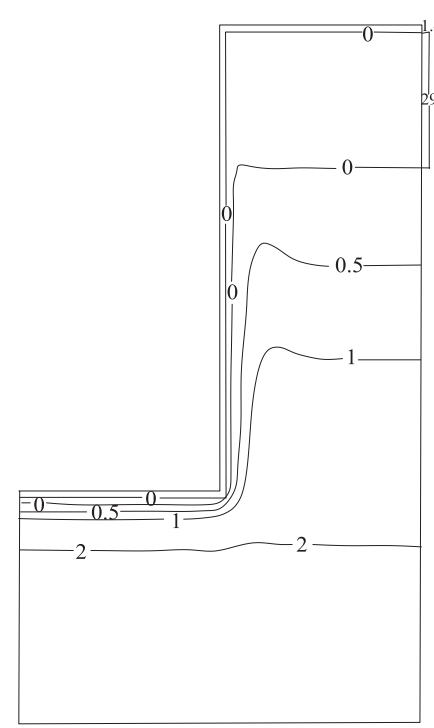

(1 year)

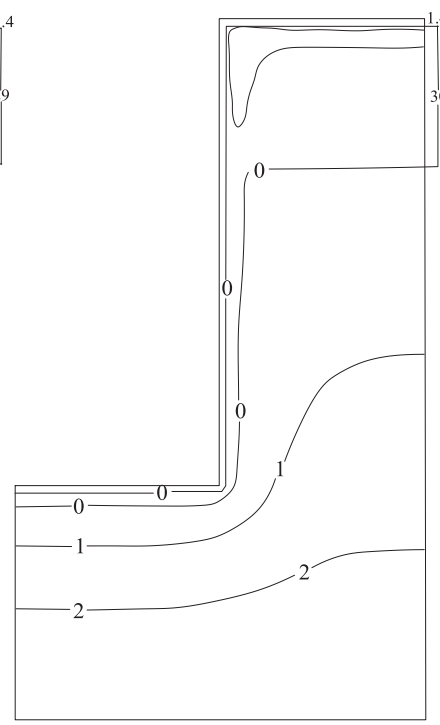

(5 years)

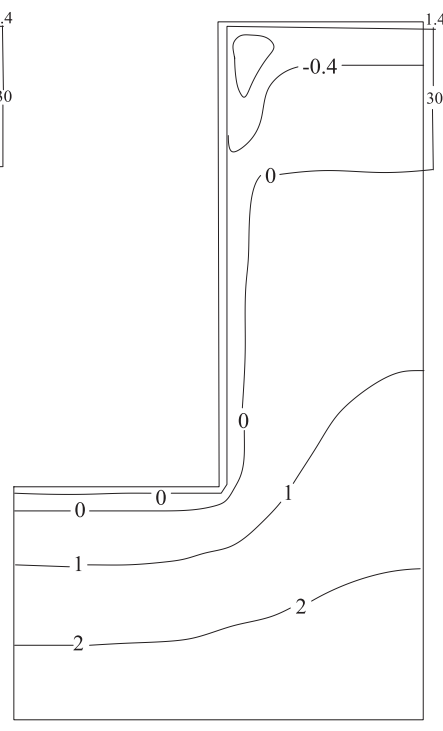

(10 years)

Figure 7. The highest temperature isotherm with the annual mean surface temperature of $-1.0^{\circ} \mathrm{C}$.

of the permafrost will develop. But the thickness is only $3 \mathrm{~m}$ until the tenth year.

We can see that because of the negative temperature, a thin layer of the permafrost can form around the pit bottom and edge. The thickness of the permafrost has decreased with the increase in the annual mean surface temperature. As the elapse of exploitation life, the permafrost degradation has not happened. This is mainly due to the fact that the negative temperature is given to the boundary condition of the average annual surface temperature around the pit edge. Thus the ground temperature has gradually decreased. But once the surface temperature rises due to open mining, the permafrost will disappear with the increase in exploitation life. The maximum frozen-thawing depth is not more than $2 \mathrm{~m}$ without considering the solar radiation, the climate conditions and the geological condition around the pit edge. But when considering these complex factors, the maximum thaw depth will be more than $2 \mathrm{~m}$.

\section{PROTECTION MEASURES OF PERMAFROST ENVIRONMENT IN COAL- MINING AREA}

Coal mining inevitably influences the permafrost environment in permafrost regions. It is a must to take effective measures to 


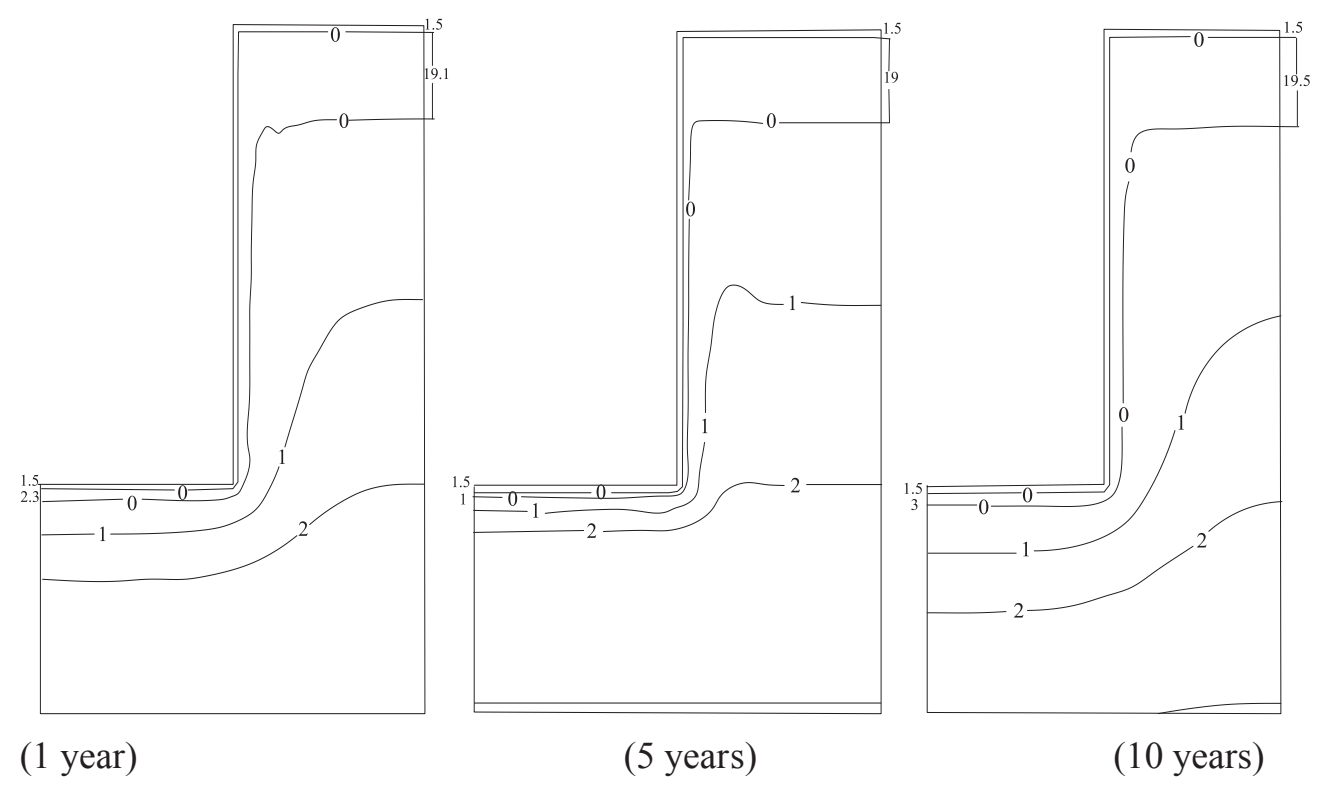

Figure 8. The highest temperature isotherm with the annual mean surface temperature of $-0.5^{\circ} \mathrm{C}$.

avoid the deterioration of frozen-soil environment. On the one hand, we should realise the seriousness of the influence of coal mining on the frozen-soil environment and should make some active measures and methods in the planning of mining area and avoid the influence of the mining process on the frozen-soil environment. On the other hand, we should take some positive and effective measures to reduce the further deterioration of permafrost environment in the process of mining.

\subsection{Establishment of long-term monitoring system of the permafrost environment}

At present, the permafrost environment has, in general, changed in Muli coal mining area. The change includes the permafrost degradation and natural environment degradation in permafrost regions. The deterioration of permafrost environment in turn affects the whole process of coal mining. The whole process has the characteristics of hysteresis. So it is necessary to strengthen the permafrost environmental monitoring. It is a must to establish long-term monitoring system in order to pay close attention to the changes in the permafrost environment in the mining area. These monitoring data can provide a scientific and theoretical basis for solving the problem of frozen-soil environment. Monitoring points can be set up in the dump, mining field, mining roadway, mining subsidence area, the industrial square and roads. The monitoring key point is the change in permafrost temperature and the effect of control measures.

\subsection{Reasonable control the depth and intensity of coal mining}

The depth and the intensity of coal mining greatly influence the quality of the frozen-soil environment. Deep coal mining will produce a series of freeze-thaw erosion phenomenon, including slope mudflow and slope sliding. In addition, coal mining will have a great impact on the ecological vulnerability and the permafrost thermal stability because of the elimination of surface vegetation and destruction of the permafrost layer. So the depth and intensity of coal mining have to be controlled to decrease their impact on frozen-soil environment. And it is a must to limit the excavation area and avoid excessive indiscriminate digging (Fig. 9a). Coal gangue site close to the river should be avoided. If it is unavoidable, we should strictly delineate from the river space. And the designated area is strictly prohibited to stack coal gangue. Moreover, coal gangue site should generally select no vegetation exposed area of production area or melting zone in order to try to avoid the destruction of vegetation. The waste rock is dumped by steps and layers (Fig. 9b). The slope angle should be controlled to prevent the soil erosion and strengthen the soil-water conservation. Moreover, the stripped surface humus-rich soil should be stacked alone. When the stacking height reaches to design elevation, the humus-rich soil should be covered to the dump surface. The sod or turf should be transplanted or cultivated for the slope nursing in order to avoid freezing-thawing erosion [Wu et al. 2005].

\subsection{Take different ways in different seasons}

Permafrost is extremely sensitive to temperature. And the thermal stability of permafrost is different in different seasons. The stability of permafrost is enhanced in winter, whereas it is weak in summer. Therefore, the seasonal precipitation will increase in summer. The ponding is a serious issue in mining area. And it is prone to slope collapse because of the poor thermal stability of permafrost. So the production or non-production of coal should be limited in this season. The precipitation decreases in winter. So there is a large-scale production of coal because of the enhanced thermal stability of permafrost. The underground ice should be rapidly excavated in the construction process to avoid ground ice melting and thus affecting the production. During the cold season, we should try to use the natural cold energy of the 


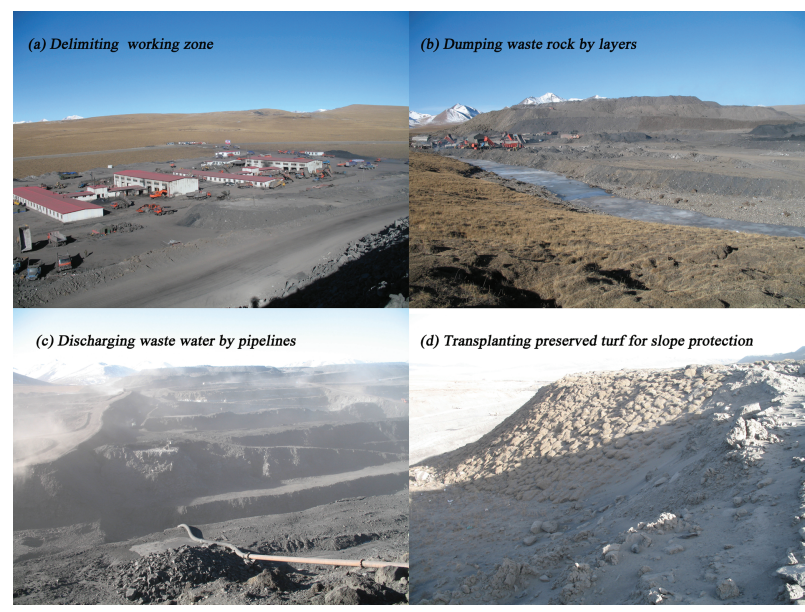

Figure 9. Photographs for the permafrost protection in Muli mining area.

surface soil with the ice for cooling in the refilling treatment in opencast mining. It could accelerate the speed of frozen-soil recovery and ecological environmental restoration.

\subsection{Protecting alpine wetland and strengthening the restoration measures of permafrost environment}

The wetland protection will greatly influence the ecological vulnerability of permafrost. So it should strengthen the monitoring of the surrounding wetlands in coal mining. At the same time, it is a must to grasp the ecological laws of wetland and pay close attention to the ecological changes in the wetland. We can take the 'artificial irrigation, natural wetland' approach to ensure integrity of the wetland ecological function. The coal mining destroys the surface and underground water. So the phenomenon of surface collapse is serious and wetland ecosystem changes severely. It should filter the natural rainfall and underground water in coal plash to treatment standards (Fig. 9c). Then the treated water can be irrigated to nearby wetlands as the supplementary water resources according to wetland ecological cycle. It can not only protect the normal water conservation function of wetland but also improve the treatment effect of waste water. The regional water resources can achieve natural purification and recycling by artificial way.

It must be not free to eradicate turf in the process of coal mining to try to reduce the destruction of vegetation on the plateau. The coal should be mined in advance in the designated area, and the turf should be transplanted before the construction. The preserved turf should be transplanted to nurse the coal

\section{REFERENCES}

CAO W., SHENG Y., CHEN J. 2008. Study on permafrost environmental assessment in Muli Coalfield of Qinghai Province. Journal of Glaciology and Geocryology, 30(1):157-164.

CAO W., SHENG Y., QIN YH., et al. 2010. Grey relation projection model for evaluating permafrost environment in Muli coal mining area, China. International Journal of Mining, Reclamation and Environment, 24(4):363-374. gangue slope after the construction (Fig. 9d). Moreover, it should strengthen the vegetation management and improve the survival rate of transplantation. And it is a must to cultivate suitable turf for the growth in cold and dry environment and transplant it into the exposed surface [Wu et al. 2005].

In addition, the effective restoration measures will have a positive impact on improving the permafrost environment. The work area especially the living area should choose to build in the exposed area without vegetation of the thawing zone. The temporary buildings should adopt the overhead structure and the roadway should pave concrete precast slab. The reclaimer should be selected in the thawing zone, flood land and bare mountain. The reclaimer field should be levelled after the completion of the project. According to the 'filling replace excavating', 'more filling than excavating' construction principle, building construction should take ventilated structure and heat-pipe cooling technology to reduce the influence on frozen-soil environment. We should also take measures to further improve the level of wastewater treatment and strengthen the land reclamation. It will have a positive role in promoting the protection of frozen-soil environment.

\section{CONCLUSIONS}

This paper analyses the status and characteristics of permafrost distribution in Muli coal mining of Qinghai Province by investigation and simulation analysis. After that, the study discusses permafrost environmental problem and its harm due to coal mining. Finally, it put forward the protection measures of frozen-soil environment in Muli mining area.

It will cause varying degrees of permafrost environment problems in coal mining area. This paper mainly analyses the influence of coal mining on permafrost environment, including the influence of other production and living facilities on the frozen-soil environment. In addition, it is necessary to study better the effect of coal mining on the permafrost environment based on a large amount of field experiments and laboratory tests.

\section{ACKNOWLEDGEMENT}

This work was supported by the National Natural Science Foundation of China (No. 41501079 and 91647103), the selfdetermined Project Funded by State Key Laboratory of Frozen Soil Engineering (No. SKLFSE-ZQ-43), the Chinese Academy of Sciences (CAS) Key Research Programme (No. KZZD-EW-13).

CHENG GD., SUN ZZ., NIU FJ. 2008. Application of the roadbed cooling approach in Qinghai-Tibet railway engineering. Cold Regions Science and Technology, 53(3): 241-258.

HILDEBRAND EE. 1983. Thaw settlement and ground temperature model for high design in permafrost. Proceedings of the 4th International Conference on Permafrost. Washington D C: National Academy Press, 492-497. 
JIN HJ., YU QH., WANG SL., et al. 2008. Changes in permafrost environments along the Qinghai-Tibet engineering corridor induced by anthropogenic activities and climate warming. Cold Regions Science and Technology, 53(3): 317-333.

JIN HJ., WANG SL., LV LZ., et al. 2009. Zonation and assessment of engineering geology for frozen-ground environments and conditions along the proposed China-Russia Crude Oil Pipeline route. Hydrogeology \& engineering geology, 36(4):102-107.

JIN HJ., WANG SL., YU QH., et al. 2006. Regionalization and assessment of environmental geological conditions of frozen soils along the Qinghai-Tibet Engineering Corridor. Hydrogeology \& engineering geology, 33(6):66-71.

MAKAROV VN. 2004. Environmental problems related to diamond mining in permafrost areas_-The case history of the Anabar placer mine, north-western Yakutia. Journal of Glaciology and Geocryology, 26(S):257-262.

NIU FJ., CHENG GD., LAI YM., et al. 2004. Instability study on thaw slumping in permafrost regions of Qinghai-Tibet Plateau. Chinese Journal of Geotechnical Engineering, 26(3):402-406.

NIU FJ., MA LF., JIN DW. 2006. Stability evaluation of slopes in permafrost region. Journal of Geotechnical Investigation \& Surveying, (6):1-3,17.

PERETRUKHIN NA., POTAUEVA TV. 1983. Laws Governing interactions between railroad roadbeds and permafrost. Proceedings of 4th International Conference on Permafrost. Washington D C: National Academy Press, 984-987.

WANG CH., ZHANG BL., LI FH., et al. 1996. Effect of gold mining on permafrost environment. Journal of Glaciology and Geocryology, 18(S):227-233.

WANG GX., CHENG GD., SHEN YP., et al. 2001. Research on Ecological Environmental Change in Changjiang-Yellow Rivers Source Regions and Their Integrated Protection. Lanzhou: Lanzhou University Press.
WANG GX., CHENG GD., SHEN YP., et al. 2004. Human engineering activities on frozen soil ecosystem change and its effect on Railway Construction. Chinese Science Bulletin, 49(15):1556-1564.

WANG SL., JIN HJ., LI SX., et al. 2000. Permafrost degradation on the Qinghai-Tibet Plateau and its environmental impacts. Permafrost and Periglacial Process, 2000,11(1):43-53.

WANG YX. 1993. The effects of gold mining on permafrost environment in Wuma mining area Inner Mogolia of China. Journal of Glaciology and Geocryology, 15(1):47-51.

WU QB., LIU YZ., TONG CJ. 2000. Interaction between frozen soil and engineering in cold regions. Journal of Engineering Geology, 8(3):281-287.

WU ZW., LIU YZ. 2005. Frozen soil foundation and engineering construction. Beijing: Ocean Press.

ZHANG FM., GAO HL. 1981. Hydrogeology and engineering geology characteristics of permafrost in Muli coalfield of Qinghai province. Qinghai Geology, (3):51-56.

ZHANG TJ., BAKER THW., CHENG GD., et al. 2008. The Qinghai-Tibet Railroad: A milestone project and its environmental impact. Cold Regions Science and Technology, 53(3):229-240.

ZHENG HL., MA FT. 1999. The effects of opencast mining on permafrost environment in coal mine of Gulian River, 27(3):60-61.

ZHENG HL., MA FT. 2000. Effect of opencast mining on permafrost environment. Opencast coal mining technology, (4):14-16.

ZHOU YW., QIU GQ., GUO DX., et al. 2000. Hydrogeology and engineering geology characteristics of permafrost in Muli coalfield of Qinghai province. Geocryology in China. Beijing: Science Press. 